\title{
Thực tiễn thi hành pháp luật về thương mại tại Việt Nam hiện nay dưới góc nhìn tham chiếu với yêu cầu của các hiệp định thương mại tự do (FTA) thế hệ mới
}

\author{
Nguyễn Trọng Điệp* \\ Khoa Luật, Đại học Quốc gia Hà Nội, 144 Xuân Thủy, Cầu Giấy, Hà Nội, Việt Nam \\ Ngày nhận 08 tháng 5 năm 2018 \\ Chỉnh sửa ngày 19 tháng 6 năm 2018; Chấp nhận đăng ngày 21 tháng 6 năm 2018
}

\begin{abstract}
Tóm tắt: Hiệp định tự do thương mại thế hệ mới với những bổ sung, tăng cường cam kết của các quốc gia trong vấn đề môi trường, lao động, sở hữu trí tuệ đã trở thành xu hướng hội nhập của các quốc gia hiện nay. Tuy nhiên, đặt trong bối cảnh Việt Nam đang đàm phán, kí kêt và thực hiện các Hiệp định này với EU, Nhật Bản, CPTPP... pháp luật thương mại Việt Nam hiện nay lại đang tạo ra những rào cản cho quá trình thực hiện các cam kết khi những khái niệm cơ bản, quy định của Luật Thương mại năm 2005 chưa đáp ứng được nội hàm các Hiệp định thế hệ mới này.
\end{abstract}

Tù khóa: Hiệp định tự do thương mại thế hệ mới, luật thương mại.

Quá trình tự do hóa thương mại được tiến hành đồng thời bởi các thỏa thuận theo hướng đa phương và các thỏa thuận theo hướng song phương. Song sự bế tắc của vòng đàm phán Đô-ha cũng tạo động lực để các quốc gia có xu hướng quay sang kí kết các FTA, dẫn đến sự gia tăng mạnh mẽ của các FTA trong những thập niên gần đây. "FTA thúc đẩy thuoong mại tư do, hợp tác kinh tế và đầu tu, uu viẹt hơn WTO” [1] ở khả năng dễ đạt đồng thuận và lĩnh vực bao quát rộng hơn so với WTO... Trong tiến trình đó, nếu như các FTA thế hệ đầu tập trung vào tự do hóa thương mại hàng hóa hữu hình, thông qua cắt giảm thuế quan và cùng

\footnotetext{
*ĐT.: 84-944551974.

Email: dieptrongnguyen@yahoo.com https://doi.org/10.25073/2588-1167/vnuls.4149
}

nhau thỏa thuận loại bỏ các rào cản phi thuế quan, thì các FTA giai đoạn hiện nay còn chứa đựng cả các nội dung, yều cầu mới mà trong khung khổ GATT/WTO chưa có quy định. "Phạm vi cam kết của FTA này còn bao gồm nhũng lĩnh vưc, nhu thuận lợi hóa thuoong mại, hoạt động đầu $t u$, mua sằm chính phủ, chính sách cạnh tranh, các biện pháp phi thuế quan, thuoong mại dịch vu, quyền sở hũu trí tuệ, co chế giải quyết tranh chấp, tiêu chuẩn và hợp chuẩn, lao động, môi truờng, thậm chí còn gắn với những vấn đề dân chủ, nhân quyền hay chống khủng bố... Các FTA với các nội dung mói nhu vậy chính là thế hệ thư ba, mà hiện nay thường được gọi là "FTA thế hệ mới" [1].

Không nằm ngoài "guồng quay" của các FTA thế hệ mới, Việt Nam đã kí kết Hiệp định Thương mại Việt Nam Hoa Kỳ, Hiệp định đối 
tác kinh tế toàn diện với Nhật bản và Hiệp định thương mại tự do song phương với Chi-lê, với Hàn Quốc; với Liên minh thuế quan Á Âu (bao gồm Nga, Armenia, Belarus, Kazakhstan và Kyrgyzstan) và đang đàm phán/ xem xét đàm phán với một loạt các nước khác, đặc biệt là Hiệp định Thương mại tự do Việt Nam $\mathrm{EU}^{1}$ (EVFTA). Có thể nói, hội nhập đã đem lại cho Việt Nam những cơ hội cũng như thách thức không nhỏ đối với hệ thống pháp luật thương mại Việt Nam, đồng thời, đặt ra không ít yêu cầu tổng thể cũng như cụ thể hoàn thiện pháp luật thương mại.

\section{Những rào cản đối với thương nhân và hiện diện của thương nhân}

Gần 15 năm thi hành Luật thương mại cho thấy những rào cản cho hội nhập xuất phát một phần từ những khái niệm, nội hàm không còn phù hợp với thực tiễn hiện nay, cụ thể:

Thư nhất, khái niệm thuoong nhân được đề cập tại Khoản 1 Điều 6 Luật thuoong mại năm 2005 không còn hợp lí và cần sớm điều chỉnh.

Khái niệm thương nhân hiện đã không bao quát được nhiều hoạt động ở khu vực "phi chính thức" cũng nhằm mục đích sinh lợi nhưng hoạt động thường xuyên như buôn bán ô tô, bất động sản. Yêu cầu thương nhân phải "có đăng kí" kinh doanh cũng không hợp lí bởi quy định này cũng đang bỏ sót các chủ thể hoạt động thương mại nhưng không đăng kí (thường gọi là thương nhân thực tế hay thương nhân khuyết tư cách). Để làm rõ thêm khái niệm về thương nhân Điều 3 Nghị định 39/2007/NĐ-CP giải thích khái niệm cá nhân hoạt động thương mại như "Buôn bán rong (buôn bán dạo) là các hoạt động mua, bán không có địa điểm cố định", "Buôn bán vặt là hoạt động mua bán

\footnotetext{
${ }^{1}$ Hiệp định Thương mại tự do Việt Nam EU (EVFTA) là một FTA thế hệ mới giữa Việt Nam và 28 nước thành viên $\mathrm{EU}$, tương tự $\mathrm{TPP}$, EVFTA có phạm vi cam kết rộng và mức độ cam kết rất cao. EVFTA đã chính thức kết thúc đàm phán ngày 01/12/2015. Hiện tại, hai bên đang tiến hành rà soát lại văn bản hiệp định và lên kế hoạch kí kêt.
}

nhũng vật dụng nhỏ lẻ có hoặc không có địa điểm cố định"; "Bán quà văt là hoạt động bán quà bánh, đồ ăn, nước uống (hàng nước) có hoặc không có địa điểm cố định". Trong so sánh với khái niệm thương nhân của các nước khác như Pháp, Mỹ̃ thì rõ ràng khái niệm về thương nhân trong Luật thương mại của Việt Nam đang nói về yếu tố hình thức nhiều hơn nội dung hoạt động và tôn chỉ của thương nhân [2].

Ngoài ra, chính những bất cập trong khái niệm về thương nhân dẫn đến thực tế là Luật Thương mại chỉ điều chỉnh đối với giao dịch có ít nhất 1 bên là thương nhân, còn những trường hợp khác thì theo sự điều chỉnh của Bộ luật Dân sự và các luật chuyên ngành khác. Điều này dẫn đến một số mâu thuẫn của Luật Thương mại với quy định của Bộ luật Dân sự về phạt vi phạm hợp đồng; mẫu thuẫn với quy định của Luật Trọng tài Thương mại về phạm vi điều chỉnh. Như vậy, bản thân pháp luật thương mại có sự mâu thuẫn đối với các luật khác trong cùng hệ thống pháp luật quốc gia, chưa nói đến việc tham chiếu với các quy định của các FTA thế hệ mới càng trở lên khó khăn hơn cho việc đàm phán, kí kết, thi hành các FTA hay nội luật hóa các quy định của FTA trong lĩnh vực thương mại.

Thư hai, quy định về sư hiện diện của thuoong nhân tại Việt Nam không còn phù hợp với xu hướng trong các FTA thế hệ mới.

Nghị định 07/2016/NĐ-CP hướng dẫn Luật Thương mại về văn phòng đại diện, chi nhánh của thương nhân nước ngoài tại Việt Nam quy định: Truờng hợp việc thành lập Văn phòng đại diện, Chi nhánh của thuoơng nhân nuớc ngoài

\footnotetext{
$\overline{2}$ Luật Thương Mại Pháp quy định thương nhân là người thực hiện những hành vi thương mại và đó là nghề thương xuyên của họ. Theo Điều 104 Bộ luật Thương Mại Hoa Kỳ thì thương nhân là những người thực hiện các nghiệp vụ đối với một loại nghề nghiệp nhất định là đối tượng của các hợp đồng Thương Mại. Một số quốc gia khác còn đưa thêm một dấu hiệu của thương nhân là phải thực hiện các hành vi Thương Mại nhân danh mình và lợi ích của bản thân mình. Như vậy, trong pháp luật của các nước thường chỉ xác định điều kiện trở thành thương nhân dựa trên yếu tố cơ bản nhất, bản chất nhất đó là "thực hiện hoạt động thương mại".
} 
hoạt động trong các ngành được quy định tại văn bản quy phạm pháp luật chuyên ngành thì thưc hiện theo quy định của văn bản quy phạm pháp luật chuyên ngành đó. Đồng thời, quy định cũng cho phép thương nhân nước ngoài được thành lập Văn phòng đại diện, Chi nhánh của mình tại Việt Nam theo cam kết của Việt Nam trong các điều ước quốc tế mà Việt Nam là thành viên. Việc dẫn chiếu quyền thành lập hiện diện thương mại sang điều ước quốc tế là không khả thi bởi theo Luật điều ước quốc tế, cam kết quốc tế lại không có giá trị áp dụng trực tiếp. Trong khi đó, nếu so sánh với Nghị định số 72/2006/NĐ-CP trước đây (hiện đã bị thay thế bởi Nghị định 07/2016/NĐ-CP) thì lại quy định rõ hơn về việc cho phép thành lập VPĐD cho tất cả các lĩnh vực, và Chi nhánh trong trường hợp thương nhân mua bán hàng hóa hoặc hoạt động liên quan trực tiếp tới mua bán hàng hóa.

Tham chiếu với cam kết quốc tế của Việt Nam thì: Về Văn phòng đại diện: Việt Nam đã cam kết mở cửa hoàn toàn cho thương nhân nước ngoài mở văn phòng đại diện tại Việt Nam trong cả WTO, CPTPP và EVFTA. Về chi nhánh: Trong cả WTO, CPTPP và EVFTA, Việt Nam không cam kết cho phép thương nhân nước ngoài thành lập chi nhánh ở Việt Nam trừ các trường hợp mở cụ thể cho từng ngành. Riêng CPTPP Việt Nam có mức mở cửa rộng hơn, cho phép thành lập chi nhánh trong 6 lĩnh vực liệt kê ngoài các cam kết cho phép thành lập chi nhánh trong những ngành cụ thể trong Danh mục các biện pháp không tương thích. Ngoài ra, trong hoạt động đầu tư theo hợp đồng hợp tác kinh doanh (BCC), góp vốn, đầu tư $100 \%$ vốn nước ngoài: thì trong cả WTO, CPTPP và EVFTA Việt Nam không giới hạn các hình thức hiện diện thương mại này của các nhà đầu tư nước ngoài ở Việt Nam trừ trường hợp có hạn chế rõ ràng được nêu trong Biểu cam kết hoặc trong Danh mục biện pháp không tương thích.

Bởi vậy, trong thời gian tới pháp luật thương mại cần sửa đổi vấn đề này. Cụ thể, cần sửa Nghị định 07/2016/NĐ-CP để quy định rõ về điều kiện đối với việc thành lập VPĐD và chi nhánh. Luật Đầu tư 2014 và Nghị định 118/2015/NĐ-CP cũng cần xem xét lược bỏ các quy định dẫn chiếu trực tiếp tới việc áp dụng cam kết bởi các cam kết không có giá trị áp dụng trực tiếp, đồng thời quy định rõ hơn về các trường hợp pháp luật không có quy định (phân biệt với trường hợp pháp luật có quy định nhưng áp dụng chung cho các chủ thể, không phân biệt trong nước hay nước ngoài.

Trong đối chiếu với các FTA thế hệ mới, có hai chủ thể trong quan hệ thương mại đáng phải chú ý là: (1) các doanh nghiệp vừa và nhỏ; (2) doanh nghiệp nhà nước. Các FTA khác đều quan tâm đến hai chủ thể này theo hướng tăng tính cạnh tranh, độc lập của doanh nghiệp nhà nước và tạo cơ chế thông thoáng, ưu đãi, chính sách bảo hộ đối với doanh nghiệp vừa và nhỏ.

\section{Những rào cản liên quan tới hoạt động thương mại của thương nhân}

Thư nhất, các quy định liên quan tới hợp đồng mua bán hàng hóa quốc tế còn nhiều bất cập.

Liên quan tới quy định của Luật thương mại về hợp đồng mua bán hàng hóa quốc tế, một số bất cập đã và đang gây cản trở khá nhiều tới việc lựa chọn áp dụng pháp luật Việt Nam trong thực tiễn thương mại, cụ thể:

- Quy định về thời điểm chuyển quyền sở hữu hàng hóa tại Điều 62 Luật Thương mại: Luật quy định quyền sở hữu hàng hóa được chuyển từ bên bán sang bên mua kể từ thời điểm hàng hóa được chuyển giao, có thể hiểu rằng khi hàng xuống cảng thì đã mặc nhiên coi là chuyển quyền sở hữu cho người mua hàng, đây là một điều cực kỳ bất lợi cho bên mua và không phù hợp với thông lệ quốc tế. Thông lệ quốc tế quy định chuyển quyền sở hữu cho người mua kể từ khi người này nhận được các chứng từ định đoạt về hàng hóa [2].

- Quy định về thời điểm chuyển rủi ro từ Điều 57 đến Điều 61 Luật thương mại: hợp đồng có đối tượng là hàng hoá đang trên đường vận chuyển thì rủi ro về mất mát hoặc hư hỏng 
hàng hoá được chuyển cho bên mua kể từ thời điểm giao kết hợp đồng. Quy định này cho phép xác định thời điểm rủi ro được chuyển sang người mua trở nên dễ dàng hơn. Tuy nhiên dưới góc độ thực tiễn thì quy định này chưa thực sự phù hợp. Vì rủi ro có thể phát sinh kể từ thời điểm hàng hóa không còn nằm trong tầm kiểm soát của người bán, tức là thời điểm hàng hóa được người bán giao cho người vận chuyển và rất có thể hàng hóa bị hư hỏng trước thời điểm kí kết hợp đồng. Về vấn đề này, pháp luật thương mại Việt Nam nên tham khảo Công ước Viên năm 1980 trong đó quy định thời điểm chuyển rủi ro là thời điểm hàng hóa được giao cho người chuyên chở là người đã phát hành chứng từ xác nhận hợp đồng vận chuyển. Trừ trường hợp lúc kí kết hợp đồng mua bán, người bán đã biết hoặc không thể không biết rằng hàng hóa đã bị mất mát hay hư hỏng nhưng không thông báo cho người mua [2].

- Quy định về chế tài trong thương mại tại Điều 292 Luật Thương mại: buộc thực hiện đúng hợp đồng, phạt hợp đồng, tạm ngừng thực hiện hợp đồng, đình chỉ thực hiện hợp đồng, hủy bỏ hợp đồng là các chế tài cơ bản được ghi nhận. Từ thực tiễn thực hiện hợp đồng thương mại, việc áp dụng các quy định về chế tài thương mại đã nảy sinh những bất cập, thể thiện tính hạn chế của một số điều luật hiện hành. Như đối với khái niệm chế tài "Buộc thực hiện đúng hơp đồng”, một phần trong định nghĩa về hình thức buộc thực hiện đúng hợp đồng thể hiện tính không khả thi, cụ thể là cụm từ "thực hiện đúng hợp đồng" là khó có thể thực hiện đặc biệt là trường hợp vi phạm hợp đồng về mặt thời hạn. Để nâng cao tính khả thi đối với quy định về buộc thực hiện đúng hợp đồng, nên xây dựng lại khái niệm về chế tài này theo hướng: "Buộc thưc hiện đúng hợp đồng là việc bên bi vi phạm yêu cầu bên vi pham tiếp tục thưc hiện hợp đồng hoạc dùng các biện pháp khác để hợp đồng được thực hiện và bên vi phạm phải chịu chi phi phát sinh". Ngoài ra, về chế tài phạt vi phạm hợp đồng được quy định tại Điều 301 Luật Thương mại năm 2005, mức phạt không quá $8 \%$ giá trị phần nghĩa vụ hợp đồng bị vi phạm và mức phạt theo thỏa thuận được quy định tại Bộ luật Dân sự năm 2015 cho các quan hệ dân sự đang tạo rủi ro cho các bên khi lựa chọn mức phạt vi phạm. Mặc dù Khoản 1 Điều 3 Luật Thương mại 2005 thì mức phạt $8 \%$ chỉ áp dụng trong hoạt động thương mại là hoạt động nhằm mục đích sinh lợi, bao gồm mua bán hàng hoá, cung ứng dịch vụ, đầu tư, xúc tiến thương mại và các hoạt động nhằm mục đích sinh lợi nhưng một vấn đề đặt ra, nếu trong hợp đồng hai bên thỏa thuận mức phạt vượt quá $8 \%$ giá trị hợp đồng, ví dụ: hai bên thỏa thuận, mức phạt $30 \%, 200 \% \ldots$ thì sẽ xử lí như thế nào? Liền quan đến vấn đề này, có hai quan điểm như sau: Quan điểm thứ nhất cho rằng, việc thỏa thuận này là vô hiệu, vì vậy khi giải quyết tranh chấp về yêu cầu phạt vi phạm hợp đồng, không chấp nhận yêu cầu này bởi vì xem như hai bên không có thỏa thuận. Quan điểm thứ hai cho rằng, việc thỏa thuận vượt quá $8 \%$ chỉ vô hiệu một phần đối với mức phạt vượt quá $8 \%$ còn điều khoản phạt vi phạm hợp đồng hoàn toàn có hiệu lực, trong trường hợp này có thể áp dụng mức tối đa $8 \%$ yêu cầu của bên bị vi phạm, phần vượt quá không được chấp nhận [3]. Từ thực tiễn xét xử các vụ tranh châp kinh doanh, thương mại, các tòa án thường chấp nhận quan điểm thứ hai, nghĩa là nếu hai bên thỏa thuận vượt quá $8 \%$ thì sẽ áp dụng mức phạt từ $8 \%$ trở xuống để giải quyết yêu cầu bồi thường cho bên bị vi phạm ${ }^{3}$. Tôi cho rằng, điều này hoàn toàn hợp lí, bởi vì, bản chất hợp đồng là ý chí của các bên, trong trường hợp này các bên hoàn toàn chấp nhận sẽ chịu phạt nếu vi phạm hợp đồng, còn việc thỏa thuận mức phạt vượt quá giá trị hợp đồng là do hai bên chưa hiểu biết đầy đủ quy định của Luật Thương mại 2005 chứ không có nghĩa là không có điều khoản về phạt vi phạm. Thực tế,

\footnotetext{
$\overline{3}$ Tòa án Nhân dân Tối cao (2009), Quyết định giám đốc thẩm số 03/2009/KDTM-GĐT ngày 09/04/2009 về vụ tranh chấp hợp đồng mua bán hàng hóa: Tòa xác định các đương sự không thống nhất được với nhau về mức phạt sau mỗi lần đối chiếu công nợ và mức phạt do các đương sự đưa ra là: 5\%/tháng; $10 \% /$ tháng; $15 \% /$ tháng không phù hợp quy định nên tòa áp dụng mức tối đa $8 \%$ giá trị phần nghĩa vụ vi phạm hợp đồng theo Luật Thương mại.
} 
đã có những vụ án các bên viện dẫn "mức phạt 8\%" nhưng không được áp dụng vì không có căn cứ phạt được ghi nhận trong nội dung điều khoản thỏa thuận ${ }^{4}$.

Liên quan đến vấn đề này, tôi cho rằng cần phải xem xét lại mức giới hạn tối đa mức phạt $8 \%$, sửa đổi theo hướng tăng giới hạn mức phạt vi phạm hợp đồng hoặc không giới hạn mức phạt tối đa.

Về mối quan hệ giữa chế tài phạt vi phạm và chế tài buộc bồi thuờng thiệt hại quy định tại Điều 307 Luật Thương mại 2005, mặc dù hiểu rằng các nhà làm luật muốn nhấn mạnh việc chế tài phạt vi phạm có thể áp dụng đồng thời với chế tài buộc bồi thường thiệt hại, hay nói cách khác, việc áp dụng chế tài phạt vi phạm không làm mất quyền áp dụng chế tài buộc bồi thường thiệt hại của bên bị vi phạm. Tuy nhiên, nội dung này đã được ghi nhận trong Điều 316: "Một bên không bị mất quyền yêu cầu bồi thuờng thiệt hại đối với tổn thất do vi phạm hợp đồng của bên kia khi đã áp dụng các chế tài khác”. Như vậy, theo quy định tại Điều 316, thì chế tài buộc bồi thường thiệt hại có thể áp dụng cùng một lúc với các chế tài khác bao gồm chế tài phạt vi phạm. Do đó, việc đặt ra một điều luật riêng để điều chỉnh mối quan hệ giữa chế tài phạt vi phạm và bồi thường thiệt hại như trong Điều 307 là không cần thiết. Không những thế, nội dung của Điều 307 lại chưa hoàn chỉnh khi quá nhấn mạnh đến căn cứ áp dụng của điều khoản phạt vi phạm mà không đề cập đến căn cứ áp dụng của chế tài buộc bồi thường thiệt hại nên

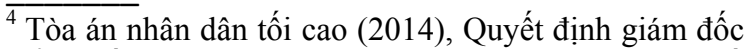
thẩm số 70/2014/KDTM-GĐT ngày 29/12/2014 về việc tranh chấp hợp đồng mua bán hàng hóa: có xác định Hợp đồng kinh tế giữa các bên có điều khoản quy định "Hai bên cam kết thực hiện nghiêm túc các điều khoản đã thỏa thuận, không được đơn phương thay đổi hoặc hủy bỏ hợp đồng. Bên nào không thực hiện hoặc đơn phương đình chỉ thực hiện hợp đồng mà không có lí do chính đáng thì sẽ bị phạt $8 \%$ trị giá hợp đồng áp dụng theo mức phạt của Luật thương mại” nhưng bị đơn vẫn thực hiện hợp đồng cũng không đơn phương đình chỉ hợp đông mà chỉ chậm thanh toán và đã phải chịu tiên lãi do chậm thanh toán nên bên nguyên không có quyền phạt vi phạm.
}

dẫn đến những lúng túng và hiểu nhầm cho các thương nhân khi áp dụng. Để giải quyết tình trạng như đã nêu ở trên, theo quan điểm cá nhân, nên bỏ quy định của Điều 307. [2]

Trong đối chiếu với các FTA mà Việt Nam tham gia thì tuân thủ các thông lệ chung về thủ tục giải quyết tranh chấp thương mại, phần lớn các FTA đều áp dụng theo hệ thống giải quyết tranh chấp của WTO. Riêng giai đoạn thực thi phán quyết lại có một số vấn đề cần lưu ý là: sau khi có phán quyết các bên tranh chấp sẽ nỗ lực giải quyết việc không thực thi thông qua các thoả thuận bồi thường, trong trường hợp các bên không thể thoả thuận về mức bồi thường mới cần viện tới ban trọng tài quyết định về thời hạn thực thi cũng như mức độ đình chỉ các nghĩa vụ liên quan phù hợp. Nhưng một số FTA gần đây lại áp dụng thủ tục thực thi theo kiểu "NAFTA". Theo đó, các bên sẽ được phép áp dụng các biện pháp trả đũa mà không cần tới sự chấp thuận của ban hội thẩm và dành nghĩa vụ điều chỉnh mức độ trả đũa vượt quá mức độ vi phạm cho bên bị đơn [3]. Trong NAFTA, chính phủ Hoa Kỳ rất chú trọng tới biện pháp trả đũa để tăng cường vai trò và tính hiệu quả của việc thực thi phán quyết. Điều 2019.1 NAFTA quy định rằng, nếu ban hội thẩm quyết định một biện pháp không phù hợp với nghĩa vụ trong NAFTA hoặc gây tổn hại hoặc phương hại tới thành viên khác, và bên bị đơn không đồng thuận với một giải pháp chung thoả đáng, bên nguyên đơn có thể đình chỉnh việc áp dụng các nhượng bộ tương đương. Ban hội thẩm trong NAFTA sẽ quyết định mức độ đình chỉ các nhượng bộ của bên nguyên đơn là phù hợp hay không. Những quy định về việc thực thi phán quyết theo kiểu NAFTA được áp dụng trong Hiệp định CPTPP. So với WTO, EVFTA quy định linh hoạt hơn khi cho phép nguyên đơn không cần phải thỏa thuận với bị đơn về bồi thường tạm thời vẫn có quyền tạm hoãn các nghĩa vụ có liên quan khi bên bị đơn không thực thi phán quyết [4].

Thư hai, quy định về nhượng quyền thuơng mai chura phù hợp thông lệ quốc tế. 
Việc Việt Nam kí kết hai hiệp định kinh tế quan trọng là TPP (nay là CPTPP) và EVFTA đã gỡ bỏ rào cản thuế quan giữa nước ta với các quốc gia thành viên EU và 10 nước cộng đồng kinh tế CPTPP, trong đó có những thị trường nhượng quyền trọng điểm là Canada, Úc, Nhật. Điều này cũng làm cho thị trường nhượng quyền của Việt Nam trở nên sôi động cho cả bên bán và bên mua. Tuy nhiên, Luật Thương mại 2005 lại chưa theo kịp với những thay đổi này, khi hiện nay hai khái niệm là "nhượng quyền thương mại" và "quyền thương mại" chưa được quy định đầy đủ và trong một vài trường hợp được quy định không thống nhất giữa các văn bản quy phạm pháp luật. Quyền và nghĩa vụ của bên nhượng quyền và bên nhận quyền trong quan hệ nhượng quyền thương mại; trình tự, thủ tục, chi phí liên quan đến hoạt động nhượng quyền thương mại đều là những vấn đề chưa được làm rõ, chưa hợp lí, chưa thống nhất. Đối chiếu với các cam kết của Việt Nam tại WTO, CPTPP, EVFTA pháp luật thương mại Việt Nam hiện nay không có hạn chế nào về hình thức hiện diện của nhà đầu tư nước ngoài trong dịch vụ này. Bởi vậy hiện cũng không có căn cứ nào để xác định pháp luật thương mại Việt Nam đã tuân thủ cam kết WTO về việc cho phép nước ngoài thành lập chi nhánh kinh doanh nhượng quyền thương mại ở Việt Nam hay chưa. Từ đó cũng chưa thể coi pháp luật thương mại Việt Nam đã phù hợp với cam kết $\mathrm{WTO}, \mathrm{EVFTA}$ và $\mathrm{CPTPP}$ về vấn đề nhượng quyền thương mại [5].

Bởi vậy, thời gian tới cần có một khái niệm hoàn chỉnh hơn về nhượng quyền thương mại, thể hiện được bản chất của hoạt động thương mại này, trong đó:(i) các bên trong quan hệ độc lập với nhau về mặt pháp lí, tài chính và kinh doanh; (ii) đối tượng của nhượng quyền thương mại là một tập hợp tài sản thương mại vô hình thuộc quyền sở hữu của bên nhượng quyền, được gọi là quyền thương mại; (iii) có sự đồng bộ, thống nhất về mặt hình thức biểu hiện đối với cách thức tiến hành hoạt động thương mại của hệ thống nhượng quyền thương mại. Cần phải sửa đổi khái niệm nhượng quyền thương mại theo hướng quan niệm đây là quyền tiến hành kinh doanh trên cơ sở khai thác thương mại một tổng thể các đối tượng của quyền sở hữu công nghiệp được bên nhượng quyền cấp cho bên nhận quyền thay vì cho rằng quyền thương mại là quyền kinh doanh tổng thể các đối tượng của quyền sở hữu công nghiệp. Đồng thời cũng cần làm rõ các yếu tố đặc trưng của quyền thương mại - là một gói các quyền sở hữu công nghiệp, sở hữu trí tuệ có liên quan đến nhãn hiệu hàng hóa, tên thương mại, biểu tượng kinh doanh, kiểu dáng công nghiệp, bí quyết kinh doanh, bằng sáng chế... đặc biệt nhấn mạnh tới sự kết hợp trong một thể thống nhất - một gói giữa các đối tượng này.

Bổ sung quy định tại Nghị định 35/2006/NĐ-CP về chi nhánh của doanh nghiệp nước ngoài tại Việt Nam trong lĩnh vực nhượng quyền thương mại, theo đó cho phép việc mở chi nhánh và có thể đặt yêu cầu về cư trú đối với Trưởng Chi nhánh.

Thư ba, cần bổ sung quy định về hoạt động quảng cáo của thuoong nhân nhằm định huớng nhung đồng thời đảm bảo sụ tuân thủ pháp luạt.

Điều 40 Luật Thương mại 2005 hiện nay cho phép một doanh nghiệp trong nước được hợp tác, đầu tư với nước ngoài trong hoạt động quảng cáo theo hình thức liên doanh và hợp đồng hợp tác kinh doanh. Còn theo Điều 41 của Luật, Văn phòng đại diện của doanh nghiệp quảng cáo nước ngoài chỉ được xúc tiến quảng cáo, không được trực tiếp kinh doanh dịch vụ quảng cáo khi đáp ứng các yêu cầu về hồ sơ, trình tự, thủ tục cấp phép thành lập văn phòng đại diện của doanh nghiệp quảng cáo nước ngoài tại Việt Nam.

Theo các cam kết của Việt Nam tại WTO và EVFTA, thì Việt Nam cho phép nhà đầu tư nước ngoài đầu tư dưới hình thức liên doanh hoặc hợp đồng hợp tác kinh doanh với doanh nghiệp Việt Nam đã được cấp phép kinh doanh quảng cáo. Theo CPTPP, Việt Nam cam kết mở cửa đầu tư không hạn chế cho dịch vụ này. Do đó CPTPP mở cửa rộng hơn nhiều so với WTO và EVFTA trong lĩnh vực này. Tuy nhiên, kết hợp với nguyên tắc tối huệ quốc của EVFTA thì Việt Nam cũng phải dành cho nhà đầu tư $\mathrm{EU}$ 
đối xử tương tự về thành lập hiện diện thương mại trong lĩnh vực này. Vì vậy, để pháp luật Việt Nam tương thích với các cam kết quốc tế thì cần đưa quy định cụ thể về điều kiện đầu tư vào lĩnh vực này vào văn bản thực thi riêng CPTPP về đầu tư (để bảo đảm tính minh bạch về quy định mở cửa thị trường, và chỉ áp dụng riêng đối với nhà đầu tư CPTPP) [6].

\section{Những rào cản pháp luật thương mại trong mối tương quan với một số cam kết về môi trường, lao động, sở hữu trí tuệ}

Theo đó, không chỉ các nội dung liên quan đến tự do hóa thương mại mà cả các nội dung phi thương mại. Các FTA thế hệ mới là những hiệp định toàn diện, không chỉ bó hẹp trong thương mại và đầu tư như các FTA truyền thống, mà với những cam kết mở cửa thị trường sâu rộng cả về thương mại hàng hóa, dịch vụ, đầu tư, bảo hộ quyền sở hữu trí tuệ ở mức cao và những cam kết về thể chế kinh tế thị trường, doanh nghiệp nhà nước, mua sắm công... nhằm tạo môi trường kinh doanh minh bạch và cạnh tranh công bằng.

Các hiệp định này còn bao gồm các nội dung tuy không phải là thương mại trực tiếp nhưng có liên quan đến thương mại, như đấu thầu, môi trường, sở hữu trí tuệ, lao động và công đoàn. Những vấn đề này tưởng trừng không có liên quan đến pháp luật thương mại. Song, trong bối cảnh toàn cầu hóa, vấn đề bảo đảm quyền lợi của người lao động ngày càng được coi trọng, vì chính người lao động là người trực tiếp sản xuất các sản phẩm hàng hóa, nên trước hết họ phải được bảo đảm các quyền, lợi ích và các điều kiện lao động cơ bản, và cũng là để bảo đảm môi trường cạnh tranh công bằng giữa các bên trong quan hệ thương mại. "Đây là cách tiếp cân trong đàm phán của các FTA thế hệ mói và đang trở thành môt $x u$ thế trong nhũng năm gần đây trên thế giới" [1] (chẳng hạn trong Hiệp định TPP đã dành hẳn một chương 19 với 15 điều quy định về lao động).

Bên cạnh đó, khi tham gia EVFTA, Việt Nam vấp phải khó khăn trong việc tuân thủ những quy định về sở hữu trí tuệ, lao động và môi trường từ EVFTA nhu: [7]

Thư nhất, về các cam kết trong lĩnh vực sở hĩu trí tuệ:

Trong khi Việt Nam còn khá thờ ơ với vấn đề sở hữu trí tuệ, thì đây lại là yêu cầu đặt lên hàng đầu từ phía EU. Thậm chí, đòi hỏi về bảo hộ sở hữu trí tuệ của nhà đầu tư $\mathrm{EU}$ còn cao hơn đòi hỏi về quyền sở hữu trí tuệ trong WTO. Việt Nam cần đặc biệt chú ý tới những quy tắc về sở hữu trí tuệ trong EVFTA để có thể khai thác được lợi ích từ hiệp định này. Vấn đề sở hữu trí tuệ trong EVFTA được đề cập khá nhiều với 4 phần, 62 điều và 2 phụ lục, trong đó đề cập tới nhiều vấn đề pháp lí mới như bảo hộ chỉ dẫn địa lí; quyền tác giả trong môi trường số; thủ tục xác lập quyền sở hữu công nghiệp và khả năng thực thi quyền sở hữu trí tuệ. Ví dụ, trong vấn đề sở hữu công nghiệp, EVFTA chú trọng việc cam kết của các bên trong việc tạo điều kiện thuận lợi cho phép xác lập quyền sở hữu công nghiệp cả trong và ngoài nước, đơn giản hóa quy trình đăng kí (có thể tham khảo mô hình của Singapore). Những cam kết này đòi hỏi Việt Nam phải ban hành các quy định hướng dẫn mới về quy trình thực hiện đăng kí bảo hộ mới theo các đòi hỏi từ EVFTA.

Đối với quyền tác giả, EVFTA cũng đặt ra yêu cầu cho các bên tham gia trong vòng 2 năm sau khi Hiệp định có hiệu lực, phải gia nhập các điều ước của Tổ chức sở hữu trí tuệ thế giới về quyền tác giả và quyền liên quan trên môi trường internet, và thể hiện trách nhiệm của mình trong việc ngăn ngừa các hành vi xâm phạm quyền tác giả trên môi trường internet.

Thư hai, về các cam kết trong sủ dụng lao động:

Dù có nhiều nỗ lực nhưng tại các DN Việt Nam vẫn tồn tại vướng mắc khi áp dụng các tiêu chuẩn lao động. Những vướng mắc phổ biến liên quan đến việc người lao động làm thêm quá số giờ quy định; quy định về nghỉ tuần, nghỉ lễ; môi trường làm việc, vệ sinh an toàn lao động; quyền tham gia bảo hiểm xã hội, bảo hiểm y tế đầy đủ, quyền được hỗ trợ của lao động nữ nơi làm việc và nuôi con 
nhỏ... Nếu không giải quyết, vấn đề này, có thể là một rào cản lớn đối với hàng xuất khẩu của Việt Nam sang EU.

Dưới góc độ chuyên môn hóa, khả năng tham gia vào việc gia tăng giá trị hàng hóa nội khối trong khu vực thương mại tự do của Việt Nam còn bất cập. Trong quá trình hội nhập, Việt Nam chưa đủ lao động có trình độ cao trong hầu hết các ngành, đặc biệt là ngành công nghệ cao, ngành dịch vụ đòi hỏi kĩ năng chuyên nghiệp. Nhìn chung, việc làm có thể gia tăng nhưng tình trạng dư thừa lao động ở một số ngành nghề tạm thời vẫn có thể xảy ra. Cơ cấu lao động theo vùng miền, ngành nghề, giới tính, độ tuổi, trình độ, mức thu nhập lao động cũng thay đổi. Hội nhập và dỡ bỏ rào cản thương mại sẽ tạo ra thất nghiệp trong từng thời điểm nhất định. Môi trường cạnh tranh sẽ trở nên khốc liệt hơn đối với các doanh nghiệp vừa và nhỏ. Do đó, "khi đàm phán và ki kết các hiệp định thuoong mại tư do, Việt Nam cần gắn với chiến luợc phát triển kinh tế xã hội dài hạn và tiến trình tái co cấu nền kinh tế và đổi móri mô hình tăng truơong” [8].

Thư ba, về các cam kết liên quan tới bảo vệ môi trưòng:

Các hiệp định FTA song phương và đa phương thế hệ mới không riêng gì EVFTA có xu hướng đưa các nội dung về môi trường và phát triển bền vững thành một chương trong hiệp định. Theo đó, nội dung cam kết liên quan tới môi trường thường đề cập tới các mục tiêu đặt ra cho các bên; cơ chế hợp tác và ở mức độ cam kết sâu hơn thì có thể đưa ra những tiêu chuẩn cao, giải quyết tranh chấp có trừng phạt hoặc bồi thường thương mại liên quan tới môi trường. Đối với EVFTA, vấn đề môi trường được đề cập tại Chương Phát triển bền vững của Hiệp định cũng với một mục tiêu hướng tới sự hỗ trợ lẫn nhau về chính sách và thực thi pháp luật liên quan tới môi trường. Cụ thể, EVFTA đặt ra 2 nhóm vấn đề môi trường đòi hỏi sự cam kết của Việt Nam bao gồm: (1) nghĩa vụ xây dựng chính sách và pháp luật môi trường trong nước theo các tiêu chuẩn cao; và (2) nghĩa vụ thực hiện các cam kết quốc tế về môi trường trong các Hiệp định đa phương. Ngoài ra,
EVFTA cũng đòi hỏi các bên có cam kết trong các vấn đề môi trường cụ thể như: biến đổi khí hậu; đa dạng sinh học; khai thác thương mại lâm sản và tài nguyên biển. Những cơ chế tham vấn, giải quyết tranh chấp cũng được đề cập trong EVFTA đồng thời cơ chế này cũng tách bạch khỏi cơ chế giải quyết tranh chấp thương mại tại Chương giải quyết tranh chấp của Hiệp định.

Đến nay, liên quan tới vấn đề này, Việt Nam chưa có kinh nghiệm trong việc thực hiện các nghĩa vụ về môi trường trong khuôn khổ các ràng buộc và điều chỉnh thương mại. Đồng thời, nguồn lực dành cho hoạt động bảo vệ môi trường còn hạn chế, ý thức và năng lực của cán bộ quản lí cũng như người dân chưa cao ảnh hưởng đến việc thực thi một cách nghiêm túc các nghĩa vụ liên quan đến môi trường. Thực trạng này đặt ra những thách thức không nhỏ cho Việt Nam do những yêu cầu từ phía $\mathrm{EU}$ đối với DN xuất khẩu Việt Nam trong thực hiện các trách nhiệm về bảo vệ môi trường.

\section{Những rào cản đến từ hàng rào kĩ thuật trong thương mại hàng hóa}

Khi tham gia WTO, CPTPP và các FTA thế hệ mới, các nước (bao gồm cả Việt Nam) đều lo lắng giảm sút xuất khẩu hàng hóa, nhập khẩu ồ ạt, không bảo hộ được sản xuất trong nước. Bởi vậy, các nước thường nghĩ ngay đến việc dựng lên các rào cản kĩ thuật đối với thương mại (TBT) để xiết chặt hơn hàng hóa nhập khẩu từ các nước khác thông qua chất lượng hàng hóa; giá cả; xuất xứ... Tuy nhiên, TBT không hề muốn dựng là dựng được. Các quy định của CPTPP và $\mathrm{FTA}$ thế hệ mới đã phần nào ngăn cản vấn đề này. Theo Hiệp định thương mại tự do giũa Việt Nam và Liên minh Châu Âu (EVFTA), mà theo đó, các nội dung chính của hiệp định gồm: thương mại hàng hóa, quy tắc xuất xứ, hải quan và thuận lợi hóa thương mại, biện pháp vệ sinh an toàn thực phẩm và kiểm dịch động thực vật (SPS), hàng rào kĩ thuật trong thương mại (TBT), thương mại dịch vụ, đầu tư, phòng vệ thương mại, cạnh tranh, doanh 
nghiệp nhà nước, mua sắm của chính phủ, sở hữu trí tuệ (gồm cả chỉ dẫn địa lí), phát triển bền vững, hợp tác và xây dựng năng lực, pháp lí - thể chế. Như vậy, các bên liên quan có nghĩa vụ tuân thủ nội dung đã cam kết.

Tương tự như vậy, Hiệp định CPTPP dành hẳn Chương 8 để quy định cụ thể về Hàng rào kĩ thuật đối với thương mại. Trong đó, các bên đã nhất trí về nguyên tắc minh bạch và không phân biệt đối xử trong việc phát triển các tiêu chuẩn, quy chuẩn kĩ thuật, và quy trình đánh giá sự phù hợp, đồng thời vẫn cho phép các bên theo đuổi những mục tiêu chính đáng của mình. Các bên đồng ý hợp tác để đảm bảo rằng các tiêu chuẩn, quy chuẩn kĩ thuật này không tạo ra các rào cản không cần thiết đối với thương mại. Ngoài ra, TPP có đính kèm các phụ lục liên quan đến quy định về những ngành cụ thể để thúc đẩy cách tiếp cận pháp lí chung trên toàn khu vực CPTPP. Các ngành này gồm mỹ phẩm, thiết bị y tế, dược phẩm, các sản phẩm công nghệ thông tin và truyền thông, rượu và thức uống chưng cất, công thức độc quyền cho các loại thực phẩm đóng gói sẵn và phụ gia thực phẩm, và các sản phẩm nông nghiệp hữu cơ.

Tại Điều 8.2 của chương này có quy định: "Mục tiêu của Chuoong này, bao gồm các Phu lucc, là tạo thuận lợi cho thuoong mai, bao gồm loại bỏ các rào cản kĩ thuật không cần thiết đối với thuoong maii, tăng cuoòng tính minh bach, và đẩy mạnh hợp tác và quản li hành chính tốt”. Như vậy, để ngăn các nước thành viên lạm dụng TBT khi bắt buộc nhà nhập khẩu phải có chứng nhận tuân thủ điều kiện kĩ thuật để được nhập khẩu, Hiệp định CPTPP không cho phép nước sở tại yêu cầu cơ quan cấp chứng nhận tuân thủ này phải có hoạt động kiểm tra chứng nhận này tại nước sở tại, hay phải có văn phòng tại nước sở tại. Thêm nữa, các nước thành viên cũng phải trả lời cho một tổ chức chứng nhận tuân thủ hoạt động trong lãnh thổ nước sở tại rằng tổ chức này có đáp ứng được các điều kiện để cấp chứng nhận tuân thủ mà nước sở tại đặt ra hay không khi tổ chức này có yêu cầu [5].
Những quy định này ra đời từ thực tế rằng các nước thành viên FTA đã dùng TBT như một rào cản ngăn hàng hóa của nước khác thâm nhập vào lãnh thổ của mình bằng việc yêu cầu nhà nhập khẩu phải có giấy chứng nhận tuân thủ điều kiện kĩ thuật, nhưng giấy chứng nhận này lại phải do cơ quan có thẩm quyền của nước thành viên cấp, và vì thế nhiều lúc bị các cơ quan này làm khó, chậm trễ hoặc từ chối cấp phép, làm họ không nhập khẩu hàng hóa vào nước sở tại được [5].

Quá trình thực hiện một số các Hiệp định FTA mà Việt Nam đã tham gia kí kết gần đây cho thấy, có nhiều trường hợp hàng hóa xuất khẩu của Việt Nam bị trả lại, không ít sản phẩm của Việt Nam còn thiếu tính ổn định. Cụ thể, với những lô hàng đầu, việc kiểm soát chất lượng làm rất tốt, nhưng những lô sau thường hay có vấn đề và hàng bị trả lại, đây được coi là một bằng chứng cho thấy nguy cơ cao rằng các nước thành viên FTA có nhập khẩu hàng hóa của Việt Nam sẽ tích cực lạm dụng TBT như là một biện pháp ngăn chặn hữu hiệu sự xâm nhập của hàng hóa từ Việt Nam khi các FTA kí kêt giữa họ với Việt Nam có hiệu lực, dẫn đến giảm hoặc xóa bỏ thuế quan nhập khẩu từ Việt Nam, làm cho nhập khẩu từ Việt Nam có xu hướng tăng lên tác động tiêu cực đến sản xuất nội địa của họ. Thông thường các FTA có các điều khoản quy định chặt chẽ về áp dụng TBT, ngăn ngừa các nước thành viên lạm dụng TBT để cản trở xuất khẩu của các nước thành viên khác vào lãnh thổ của mình.

Các nước thành viên Hiệp định CPTPP đã thống nhất về một bộ quy tắc xuất xứ chung để xác định một hàng hóa cụ thể "có xuất xứ" và do vậy được hưởng thuế quan ưu đãi trong CPTPP. Hiệp định CPTPP quy định về "cộng gộp" để các nguyên liệu đầu vào từ một bên TPP được đối xử như những nguyên liệu từ một bên khác nếu được sử dụng để sản xuất ra một sản phẩm tại bất kỳ một bên TPP. Tương tự như vậy, khi tham gia EVFTA, Việt Nam cũng vấp phải những khó khăn trong việc đảm bảo quy tắc xuất xứ của EVFTA: Hiệp định EVFTA 
hướng tới mức độ xóa bỏ thuế nhập khẩu lên tới $99,2 \%$ số dòng thuế. Tuy nhiên, để được hưởng mức ưu đãi này, hàng xuất khẩu sang $\mathrm{EU}$ cần thoả mãn quy tắc xuất xứ, đây có thể là một cản trở đối với hàng xuất khẩu Việt Nam bởi nguồn nguyên liệu cho các mặt hàng xuất khẩu của Việt Nam hiện nay chủ yếu được nhập khẩu từ Trung Quốc và ASEAN. Nếu không đảm bảo được quy tắc xuất xứ, hàng xuất khẩu của Việt Nam sang EU chỉ được hưởng mức thuế đãi ngộ tối huệ quốc chứ không phải là mức thuế suất $0 \%$ trong EVFTA. Trong bối cảnh đó, giải pháp phát triển công nghiệp phụ trợ nhằm đảm bảo thoả mãn yêu cầu về xuất xứ được đưa ra. Nhà nước cần xác định về các ngành xuất khẩu mũi nhọn và quy hoạch phát triển các ngành công nghiệp phụ trợ. Bên cạnh đó, cần có chính sách ưu đãi nhằm thu hút các $\mathrm{DN}$ đầu tư phát triển các cụm sản xuất nhằm phát triển công nghiệp phụ trợ, đặc biệt DNNVV cũng như $\mathrm{DN}$ có vốn đầu tư trực tiếp nước ngoài (FDI) Xây dựng cơ chế thuận lợi thu hút FDI từ các nhà đầu tư $\mathrm{EU}$ tham gia vào quá trình sản xuất cũng như vào các hoạt động hỗ trợ xuất khẩu tại Việt Nam [7].

\section{Kết luận}

Đối với những nước có trình độ phát triển như Việt Nam thì việc tham gia vào các hiệp định thương mại "thế hệ mới" có chất lượng cao như EVFTA, CPTPP được xem là cơ hội để rà soát, điều chỉnh các quy định tiệm cận hơn với xu hướng thương mại quốc tế hiện đại. Tuy nhiên, hội nhập càng sâu cũng đặt ra thách thức đòi hỏi hệ thống quy định pháp luật cần phải được xem xét kĩ, cả về nội dung và tầm nhìn, đặc biệt là việc xác định được những rủi ro thương mại có thể phát sinh, đề ra cơ chế, giải pháp đối với các vấn đề pháp lí mới đặt ra trong quan hệ thương mại. Do vậy, việc tiếp tục rà soát, đánh giá khả năng tương thích của pháp luật Việt Nam và cơ chế bảo đảm thực hiện cam kết đóng vai trò hết sức quan trọng. Việt Nam phải đảm bảo nội lực cạnh tranh của các doanh nghiệp để phát triển trong sự ràng buộc bởi các cam kết mở cửa thị trường cũng như các Hiệp định đã, đang và sẽ đàm phán [9].

\section{Lời cảm ơn}

Bài viết này được thực hiện trong khuôn khổ đề tài QG.17.30 "Hoàn thiện pháp luật kinh doanh tại Việt Nam nhằm chuẩn bị cho việc thi hành các hiệp định thương mại tự do (FTA) thế hệ mới"; từ năm 2017 đến năm 2019 do PGS.TS Lê Thị Hoài Thu làm chủ nhiệm.

\section{Tài liệu tham khảo}

[1] Vũ Văn Hà, Vai trò của các hiệp định thuoong mại tụ do thế hệ mới trong thuong mại quốc tế, link: http://tapchitaichinh.vn/nghien-cuu--traodoi/trao-doi-binh-luan/vai-tro-cua-cac-hiep-dinhthuong-mai-tu-do-the-he-moi-trong-thuong-maiquoc-te-122913.html.

[2] Vũ Đặng Hải Yến, Báo cáo rà soát văn bản pháp luật - Luật Thuơng mại 2005.

[3] Đồng Thái Quang, Chế tài trong thuoong mại: một số bất cập và phwơng huớng hoàn thiện, link: http://phaply.net.vn/dien-dan-luat-gia/chetai-trong-thuong-mai-mot-so-bat-cap-va-phuonghuong-hoan-thien.html.

[4] Nguyễn Thị Anh Thơ, Hệ thống giải quyết tranh chấp trong khuôn khổ một số Hiệp định thuong mại tụ do mà Việt Nam là thành viên, Tạp chí Dân chủ và Pháp luật.

[5] Phạm Thị Hồng Đào, Thưc hiện Hiệp định TPP: Cần sụ hỗ trợ của nhà nước để tận dụng co hội của thị trường móit.

[6] Nguyễn Thị Thu Trang (chủ biên), Rà soát Pháp luật Việt Nam với các cam kết WTO, Hiệp dịnh thuơng mai tụ do Việt Nam - EU và Hiệp dịnh Đối tác Xuyên Thái Bình Dưong về Mở cưa Dịch vu cho đầu tư nước ngoài.

[7] Đặng Thị Huyền Anh, Hiệp định EVFTA và một số vấn đề đặt ra đối với xuất khẩu của Việt Nam vào thị trường $E U$. 
[8] Lê Mai Thanh, Yêu cầu hội nhập kinh tế quốc tế đối với việc hoàn thiện pháp luật về doanh nghiệp Việt Nam, Kỷ yếu Hội thảo Đề tài "Cải cách pháp luật về doanh nghiệp trong tiến trình hội nhập quốc tế ở Việt Nam hiện nay".
[9] Bùi Nguyên Khánh (2017, chủ nhiệm), Báo cáo đề tài cấp bộ "Cải cách pháp luật về doanh nghiệp trong tiến trình hội nhập quốc tế ở Việt Nam hiện nay”.

\title{
Implementing the Law on Commerce in Vietnam in Reference to the Requirements of New-Generation Free Trade Agreements
}

\author{
Nguyen Trong Diep \\ VNU School of Law, 144 Xuan Thuy, Cau Giay, Hanoi, Vietnam
}

\begin{abstract}
The new generation free trade agreements with the commitment of all countries in the field of environment, labour and intellectual property has become a trend ininternational integration today. However, in Vietnam, the law on commerce 2005 is creating barriers to the signing and implementing of these agreements with the EU, Japan orof the CPTPP.
\end{abstract}

Keywords: New-generation free trade agreements, law on commerce. 